\title{
Foreign Direct Investment and Economic Growth in Sri Lanka
}

\author{
N. Balamurali and C. Bogahawatte *
}

\begin{abstract}
This paper examines the relationship between foreign direct investment and economic growth of Sri Lanka for the period 1977-2003 using Johansen's full information maximum likelihood method by considering relationship between real gross domestic product, foreign direct investment, domestic investment and openness of the trade policy regime. The results indicate that foreign direct investments exert an independent influence on economic growth and there is bidirectional causality between foreign direct investment and economic growth. The finding suggests that better trade policy reforms, implementation aimed at promoting foreign direct investment and domestic investment, and restoring international competitiveness to expand and diversify the country's exports have the potential of accelerating economic growth in the future.

\section{Introduction}

The growth of foreign direct investment (FDI) has been focused in several studies examining the channels of transmission between FDI and growth. Economic models of endogenous growth were combined with studies of diffusion of technology in an attempt to show the effect of FDI on the economic growth of several economies (Lucas, 1988; Barro, 1990). In these models technology plays an important role in economic development. The extensions of the neoclassical models to allow for capital and technology

mobility of countries have reinforced the idea that low income countries tend to grow at a higher rate. The volatility of FDI and requirement for macroeconomic and financial adjustments has been identified for developing nations. De Gregrio and Guidotti (1995) indicated that financial liberalization and stabilization must be undertaken in the host countries before any increases in FDI become feasible. FDI has been seen as an effective channel to transfer technology and foster growth in developing countries within the framework of the neoclassical models (Solow, 1956).
\end{abstract}

*The authors are affiliated to the Board of study in Agricultural Economics, Postgraduate Institute of Agriculture and Department of Agricultural Economics and Business Management, Faculty of Agriculture, University of Peradeniya, respectively. 
The impact of FDI on growth rate of output was constrained by the existence of diminishing returns of physical capital. Therefore FDI could only exert an effect on the level of output per capita, but not on the growth rate. In other words, it was unable to alter the growth of output in the long run. In the context of the new theory of economic growth, FDI is considered as an engine of growth of mainstream economics. FDI is recognized not only in terms of capital formation, but also for its spill over effects on trade and technological progress. As noted by the World Bank (2002), several recent studies concluded that FDI can promote the economic development of the host country by helping to improve productivity growth and export. However, the exact relationship between foreign multinational corporations and their host countries varies considerably between countries and among industries. The characteristics of the host country and the policy environment are important determinants of net benefit of FDI.

\section{Problem Statement}

The role of FDI in the growth process has long been a topic of discussion in several countries. These discussions have provided rich insights into the relationship between FDI and growth. Although several studies on FDI and growth in developing economies exist, very few studies on this subject have been done on Sri Lanka (Athukorala, 2003; Watawala, 1992). Moreover, most of these studies provide a descriptive discussion of FDI and economic growth. These studies have employed cross section regression methodologies but recent time series studies do not uniquely support the FDI led economic growth hypotheses. The empirical evidence of recent studies is rather mixed. Some found no causality between FDI and economic growth (Jung and Marshall, 1985) others found unidirectional relationship. Chow (1995) reported bidirectional relationship between FDI and economic growth. The heterogeneity in these results may be due to different testing procedures being used to the lag structure specified or to the different filtering techniques used in the methodologies.

The general objective of this study is to examine the relationship between FDI and economic growth in Sri Lanka using recent advancement in time series techniques. The specific objectives are to identify factors affecting economic growth in the Sri Lankan economy and to test co-integration relationship between a few variables affecting FDI in Sri Lanka.

\section{Methodology}

The FDI-growth linkage assumes that FDI provides a significant contribution to economic growth. 
Assume a production function of the form,

(1)

$\mathrm{Y}=\mathrm{f}(\mathrm{FDI}, \mathrm{K}, \mathrm{L})$

where Y represents aggregate real output, $\mathrm{K}$ is the capital stock, $\mathrm{L}$ the labour force and the FDI represents the amount of foreign direct investment. The effect of trade liberalization on economic growth operates through total exports and imports to gross domestic product (GDP). As reliable data on capital stock is not available, in most studies the ratio of the gross fixed domestic investment to GDP is employed as a proxy variable to represent capital stock. In this study, the nationally owned investments defined as gross fixed domestic investment less net FDI inflows (DIN) is used as a proxy for $K$. The openness of the trade policy regime (OPEN) is represented by a proxy variable defined as ratio of total merchandise trade (imports+ exports) goods to GDP. (2)

$\mathrm{Y}=\mathrm{f}($ FDI, DIN, OPEN)

Total differentiation of equation (2) with respect to time, and division of both sides of the resulting time derivative by $\mathrm{Y}$, one can specify the linear growth model of the form:

$$
\dot{\mathrm{Y}}=\alpha_{0}+\alpha_{1} \text { FDI }+\alpha_{2} \mathrm{DIN}+\alpha_{3} \text { OPEN }
$$

where a variable with a dot over it indicates $\mathrm{dY} / \mathrm{dt}$; and $\alpha$ ' s are the respective elasticities. For the application of multivariate cointegration techniques, the equation (3) can be represented in the following linear logarithmic regression form,

(4)

$$
\begin{aligned}
& \dot{\mathrm{LY}_{\mathrm{t}}}=\alpha_{0}+\alpha_{1} \dot{\mathrm{LFDI}}_{\mathrm{t}}+\alpha_{2} \dot{\mathrm{LDIN}}_{\mathrm{t}}+ \\
& \alpha_{3} \dot{\mathrm{LOPEN}}_{\mathrm{t}}+\varepsilon_{\mathrm{t}}
\end{aligned}
$$

where $\mathrm{L}$ represents the natural logarithms of the variables and $\varepsilon$ the stochastic error term. As the first difference reflect the rate of change of each variable, equation (4) can be used to examine both the short and long-run relationship between the economic indicators. The investigation of long-run relationship between LY, LFDI, LDIN, LOPEN in a cointegration framework begins with an examination of integration properties of the data. If the variables are integrated of order one, then the determination of the cointegration rank using Johansen and Juselius (1990) maximum likelihood cointegration procedure follows. Once a long-run equilibrium relationship is established, Granger causality is then tested using the error correction formula of Engle and Granger (1987).

\section{Integration Properties of the Data}

A visual inspection of the data indicated that all the variables are non-stationary but stationary in first differences. A univariate analysis of each of the time series was undertaken to examine the presence of a unit root. The unit root tests 
employed for the study are Augmented Dickey-Fuller (ADF) test (1979) and Phillips and Perron (1988) Z(tó)- test. The Phillips and Perron test which accounts for possible correlation in the first difference of the time series using non-parametric correction is more powerful than the ADF test, particularly for small samples and is simpler to estimate.

\section{Testing for Cointegration}

Consider an unrestricted Vector Autoregression (VAR) model represented by,

$$
\begin{aligned}
& \mathrm{Y}_{\mathrm{t}}=\mu+\sum_{\mathrm{k}=1}^{\mathrm{p}} \prod_{\mathrm{k}} \mathrm{Y}_{\mathrm{t}-\mathrm{k}}+\varepsilon_{\mathrm{t}} \\
& \mathrm{t}=1, \ldots ., \mathrm{T}
\end{aligned}
$$

where $\quad \varepsilon_{\mathrm{t}}$ is $\mathrm{p}$ dimensional Gaussian error with mean zero and variance matrix $\lambda, Y_{t}$ is an $(n \times 1)$ vector of $I(1)$ variables, and $\mu$ is an (nx1) vector of constants. As $Y_{t}$ is assumed to be non-stationary, and $\Delta \mathrm{Y}_{\mathrm{t}}=\mathrm{Y}_{\mathrm{t}}-\mathrm{Y}_{\mathrm{t}-1}$, equation (5) could be rewritten in first difference notation reformulated in error correction form ,

$$
\begin{aligned}
\Delta \mathrm{Yt}= & \mu+\sum_{\mathrm{k}=1}^{\mathrm{p}-1} \Gamma_{\mathrm{k}} \Delta \mathrm{Y}_{\mathrm{t}-\mathrm{k}}+\prod \mathrm{Y}_{\mathrm{t}-1} \\
& +\varepsilon_{\mathrm{t}}
\end{aligned}
$$

$$
\text { where } \Gamma_{\mathrm{k}}=\mathrm{I}-\left(\prod_{1}-\ldots . .-\prod_{\mathrm{k}}\right) \text {; }
$$
and $\Pi=\mathrm{I}-\left(\prod_{1}, \ldots, \prod_{\mathrm{p}}\right)$. Since $\varepsilon_{\mathrm{t}}$ is stationary, the rank $\mathrm{r}$ of the long-run matrix determines how many linear combinations of $\mathrm{Y}_{\mathrm{t}}$ are stationary. If the co integrating rank $r=0$ so that $\prod=0$, the equation (6) is similar to a traditional firstdifferenced VAR model. With $0<\mathrm{r}<$ $n$, there is $r$ cointegrating vectors or $r$ stationary linear combinations of $Y_{t}$ where $\Pi=\alpha \beta$, where both $\alpha$ and $\beta$ are (nxr) matrices. The cointegrating vector $\beta$ has the property that $\beta^{\prime} \mathrm{Yt}$ is stationary although $Y_{t}$ is nonstationary. The cointegrating rank $r$ can be tested with statistics such as maximum eigen value $\left(\lambda_{\max }\right)$ test and trace test. The asymptotic critical values are in Johansen and Juselius (1990) and Osterwald-Lenum (1992).

The results of VAR models are sensitive to lag length choice (Boswijk and Frances, 1992). They suggest the use of Johansen's approach to determine the different lag lengths and to base the final choice using LR tests in the absence of serial correlation in the residuals and the significance of parameters of higher lags. A VAR model incorporating two lags of each variable is selected from the test applied.

\section{Granger Causality Tests from Error Correction Model}

In order to test whether long run growth relationship established in the 
model and the relationship will hold given the short-run disturbances, a dynamic error correction model was used based on the cointegration relationship. For this purpose the lagged residual error derived from the cointegration vector was incorporated into the general error model. This leads to specification of an error correction model. The presence of one cointegrating relationship permits the use of Engle and Granger (1987) error correction model to test for Granger causality. The error correction requirement of the model in equation (6) for the three variables is written in equation (7),

$$
\begin{aligned}
& \mathrm{m} \\
& \Delta \mathrm{LY}_{\mathrm{t}}=\beta_{1}+\sum_{\mathrm{k}=1}\left[\theta_{1 \mathrm{k}} \Delta \mathrm{LY}_{\mathrm{t}-\mathrm{k}}\right. \\
& +\gamma_{1 \mathrm{k}} \Delta \mathrm{LFDI}_{\mathrm{t}-\mathrm{k}} \\
& +\varphi_{1 \mathrm{k}} \Delta \mathrm{LDIN}_{\mathrm{t}-\mathrm{k}} \\
& \left.+\alpha_{1 \mathrm{k}} \Delta \mathrm{LOPEN}_{\mathrm{t}-\mathrm{k}}\right]+\lambda_{1} \mathrm{EC}_{\mathrm{t}-1}+\varepsilon_{1}
\end{aligned}
$$

$$
\begin{aligned}
\Delta \text { LLFDI }_{\mathrm{t}}= & \beta_{2}+\sum_{\mathrm{k}=1}^{\mathrm{m}}\left[\theta_{2 \mathrm{k}} \Delta \mathrm{LY}_{\mathrm{t}-\mathrm{k}}\right. \\
& +\gamma_{2 \mathrm{k}} \Delta \mathrm{LFDI}_{\mathrm{t}-\mathrm{k}} \\
& +\varphi_{2 \mathrm{k}} \Delta \mathrm{LDIN}_{\mathrm{t}-\mathrm{k}} \\
& \left.+\alpha_{2 \mathrm{k}} \Delta \mathrm{LOPEN}_{\mathrm{t}-\mathrm{k}}\right] \\
& +\lambda_{2} \mathrm{EC}_{\mathrm{t}-1}+\varepsilon_{2}
\end{aligned}
$$

$$
\begin{aligned}
\Delta \operatorname{LLDIN}_{\mathrm{t}}= & \beta_{3}+\sum_{\mathrm{k}=1}^{\mathrm{m}}\left[\theta_{3 \mathrm{k}} \Delta \mathrm{LY}_{\mathrm{t}-\mathrm{k}}\right. \\
& +\gamma_{3 \mathrm{k}} \Delta \text { LFDI }_{\mathrm{t}-\mathrm{k}} \\
& +\varphi_{3 \mathrm{k}} \Delta \text { LDIN }_{\mathrm{t}-\mathrm{k}} \\
& \left.+\alpha_{3 \mathrm{k}} \Delta \text { LOPEN }_{\mathrm{t}-\mathrm{k}}\right] \\
& +\lambda_{3} \mathrm{EC}_{\mathrm{t}-1}+\varepsilon_{3}
\end{aligned}
$$

$$
\begin{aligned}
\Delta \text { LLOPEN }_{\mathrm{t}}= & \beta_{4}+\sum_{\mathrm{k}=1}^{\mathrm{m}}\left[\theta_{4 \mathrm{k}} \Delta \mathrm{LY}_{\mathrm{t}-\mathrm{k}}\right. \\
& +\gamma_{4 \mathrm{k}} \Delta \text { LFDI }_{\mathrm{t}-\mathrm{k}} \\
& +\varphi_{4 \mathrm{k}} \Delta \text { LDIN }_{\mathrm{t}-\mathrm{k}} \\
& \left.+\alpha_{4 \mathrm{k}} \Delta \text { LOPEN }_{\mathrm{t}-\mathrm{k}}\right] \\
& +\lambda_{4} \mathrm{EC}_{\mathrm{t}-1}+\varepsilon_{4}
\end{aligned}
$$

In equation (7), $\mathrm{m}$ is the lag length and $\mathrm{EC}_{\mathrm{t}-1}$ is the error correction term. The coefficient of the EC contains information about whether the past values of variables affect the current value of the variables under study. The size and the statistical significance of the coefficient of the error correction model measure the tendencies of each variable to return to equilibrium. For example if $\lambda_{1}$ in equation (7) is statistically significant it means that LY responds to disequilibria in its relations with exogenous variables. According to Choudry (1995), even if the coefficients of the lagged changes of the independent variables are not statistically significant, Granger causality can still exist as long as $\lambda$ is significantly different from zero. The short-run dynamics are captured through individual coefficients of the difference terms.

The data used for the study was from 1977-2003. The data sources included Central Bank of Sri Lanka, World Bank, IMF International Financial Statistics Year books, FAO Production Year books, Board of Investment Annual Reports, Ministry of Finance, Department of Census 
and Statistics, Sri Lanka Customs reports and other sources. For the empirical analysis, GDP investments were expressed in terms of constant 1996 prices. Exports and imports included receipts on accounts of merchandise and non factor services.

\section{Results and Discussion}

In Sri Lanka, during periods of relative economic and political stability, foreign direct investment inflows have responded positively. For example, during the periods 1979-1982, 1990-1993 and 2002, foreign direct investments increased to a maximum of US\$ 242 million. In 2003, the inflows of foreign direct investments including privatization proceeds increased by US \$ 30 million. The realized inward investment flow was mainly to power and energy sectors, port related developments, telecommunications, and manufacturing. However, the net foreign direct investment was marginally lower in 2003 owing to larger outflow of US \$ 27 million as compared to outflow of US \$ 11 million in 2002 (Figure 1). The world foreign direct investment to the developing countries increased from nearly US \$ 9000 million in 1995 to US \$ 250000 million in year 2000. However, after 2001 the net foreign direct investment marginally decreased from 2001-2002 (Figure 2).

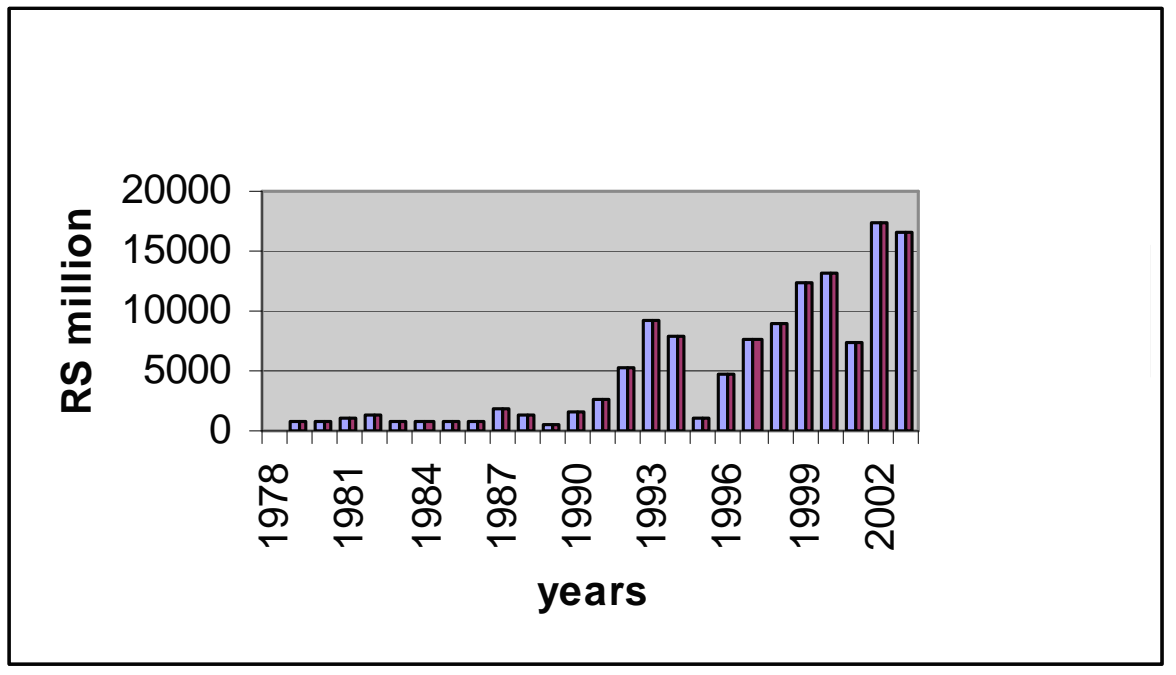

Figure 1: Net Foreign Direct Investment, Sri Lanka, 1978-2003 


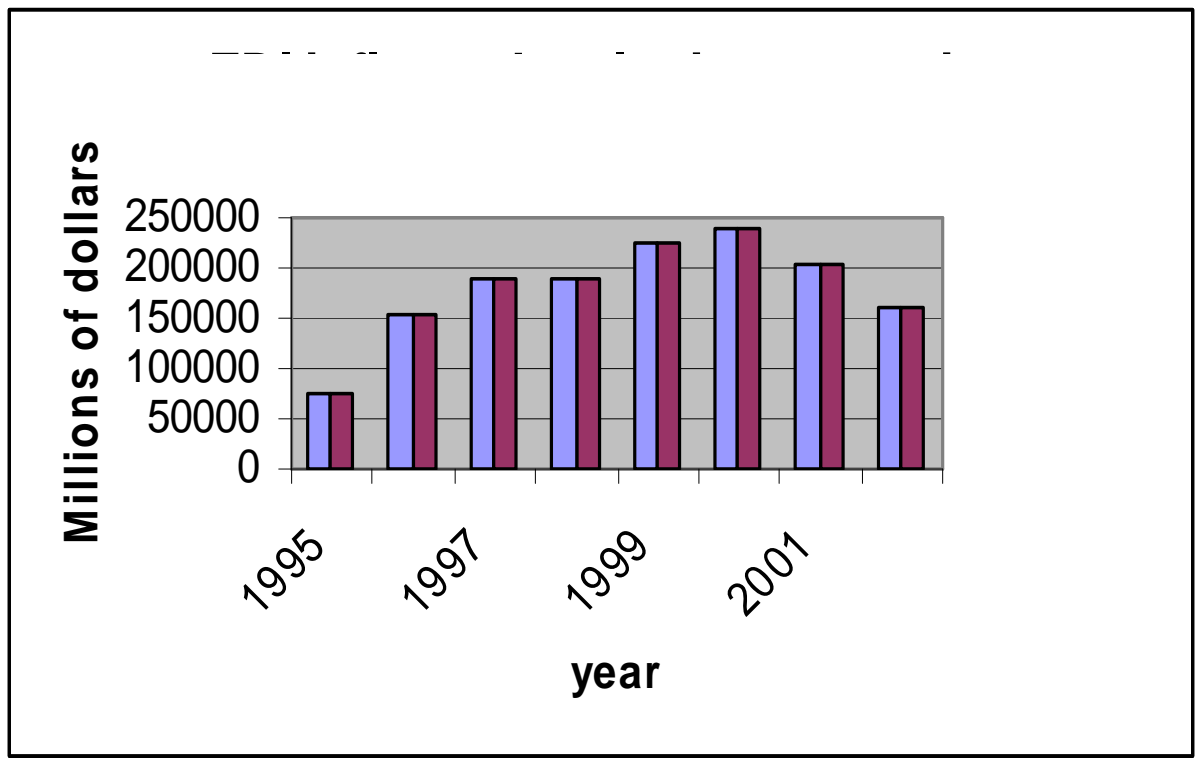

Figure 2: Foreign Direct Investment of developing countries

The results of the integration properties of the data are presented in Table 1. The lag length as determined by the Akaike Information Criteria for the ADF tests was selected to ensure that the residuals were white noise. The results of the ADF and Phillips and Perron test statistics shows that at 5\% level of significance, none of the variables represent a stationary process. However, the ADF and Phillips and Perron test statistics computed using the first difference of the series are all above 5\% critical level indicating stationarity. Since differencing produces stationarity, it is concluded that each of the series is integrated of order 1 or $\mathrm{I}(1)$.

A VAR model incorporating two lags of each variable is selected from the test applied. The results of the Johansen's test for cointegration are summarized in Table 2. The testing strategy begins with $r=0$.Using both the trace and the $\lambda_{\max }$ test statistics, one can reject $r=0$ against the alternative $\mathrm{r}=1$ and $\mathrm{r}=2$ but fails to reject the hypothesis of existence of more than one stationary linear combination.

The normalized coefficients in Table 3 are estimates for long run elasticities of GDP growth, in Sri Lanka with respect to foreign 
Table 1: Results of stationary test for the series

\begin{tabular}{lllll}
\hline Series & \multicolumn{2}{c}{ Levels } & \multicolumn{2}{c}{ First Difference } \\
\cline { 2 - 5 } & ADF & PP Z(t $\alpha)$ & ADF & Z(t $\alpha)$ \\
\hline LY & $-0.766(1)$ & $-0.55(1)$ & $-3.70(1)^{*}$ & $-4.9(1)^{*}$ \\
LFDI & $-2.21(2)$ & $-2.7(2)$ & $-5.36(1)^{*}$ & $-5.36(1)^{*}$ \\
LDIN & $-0.13(1)$ & $-0.45(1)$ & $-4.784(2)^{*}$ & $-7.25(1)^{*}$ \\
LOPEN & $-1.14(1)$ & $-0.95(1)$ & $-3.65(1)^{*}$ & $-4.83(2)^{*}$ \\
\hline
\end{tabular}

- Indicates significance at 5\% level. ADF and PP shows unit root test due to Dickey-Fuller (1981) and Philiips-Perron (1989) respectively. Numbers in parentheses indicate the number of lags in the particular ADF regressions and non parametric correction for serial correlation

Table 2: Tests for the number of cointegrating vectors using the Johansen Procedure

\begin{tabular}{cccccc}
\hline $\mathrm{H}_{0}$ & $\mathrm{H}_{\mathrm{A}}$ & $\lambda_{\max }$ test & $\Lambda_{\max }(0.95)$ & Trace test & $\begin{array}{c}\text { Trace } \\
(0.95)\end{array}$ \\
\hline $\mathrm{r}=0$ & $\mathrm{r}=1$ & $20.405^{*}$ & 13.63 & $56.288^{*}$ & 47.21 \\
$\mathrm{r} \leq 1$ & $\mathrm{r}=2$ & $14.06^{*}$ & 8.08 & $26.595^{*}$ & 22.68 \\
$\mathrm{r} \leq 2$ & $\mathrm{r}=3$ & $12.89^{*}$ & 10.67 & $16.54^{*}$ & 14.78 \\
$\mathrm{r} \leq 3$ & $\mathrm{r}=4$ & 5.60 & 8.98 & 10.32 & 12.45 \\
\hline
\end{tabular}

Cointegrating equation

$\mathrm{LY}=3404.92+0.97137 \mathrm{LFDI}+0.8837 \mathrm{LDIN}$ - 0.1744LOPEN

Note: The critical values of maximum eigen values $\left(\lambda_{\max }\right)$ and trace are taken from Osterwald-Lenum (1992) .* indicates significance at $5 \%$ level.

direct investment, domestic economy. The negative coefficient investment and ratio of for the ratio merchandise trade merchandise trade. The positive ratio may be related to the growth coefficients for foreign direct of imports compared to that of investment and domestic exports in the economy. Earlier investment show their significant studies have shown that growth of contribution to the economic exports is conducive to economic growth of the Sri Lankan 
growth. The results also showed the importance of foreign direct investment and domestic investment to economic growth (Fosu, 1990, Henrique and Sardosky, 1996). The long-run impact of foreign direct investment is greater than domestic investment on GDP growth (Figure 3 and Figure 4)

Table 3 shows the results of the error correction model. The appropriate lag length of each regressor was chosen based on the Akaike Information Criteria. All possible combinations of one to four lags were considered.
Following Hendry (1995)'s general to specific modeling approach, three lags of the explanatory variables and one of the error correction terms were first included and then insignificant variables were gradually eliminated from the model.

The $\mathrm{P}$ value from the joint significance test is for the null hypotheses that only changes in lagged value of the dependent variable affect its current changes. The significance of $\mathrm{EC}_{\mathrm{t}-1}$ is determined by the $t$ ratio of coefficient $\lambda$ in the model.

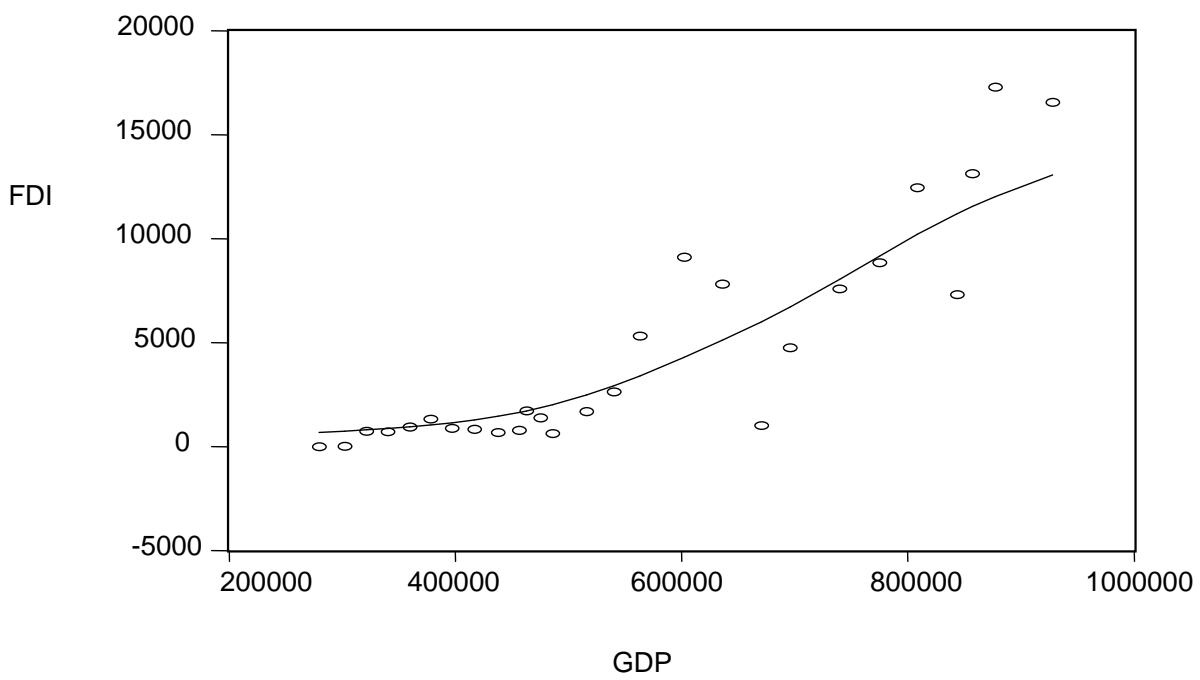

Figure 3: Relationship of Foreign Direct Investment and GDP Kernel Fit (Normal, $h=97291$.) 


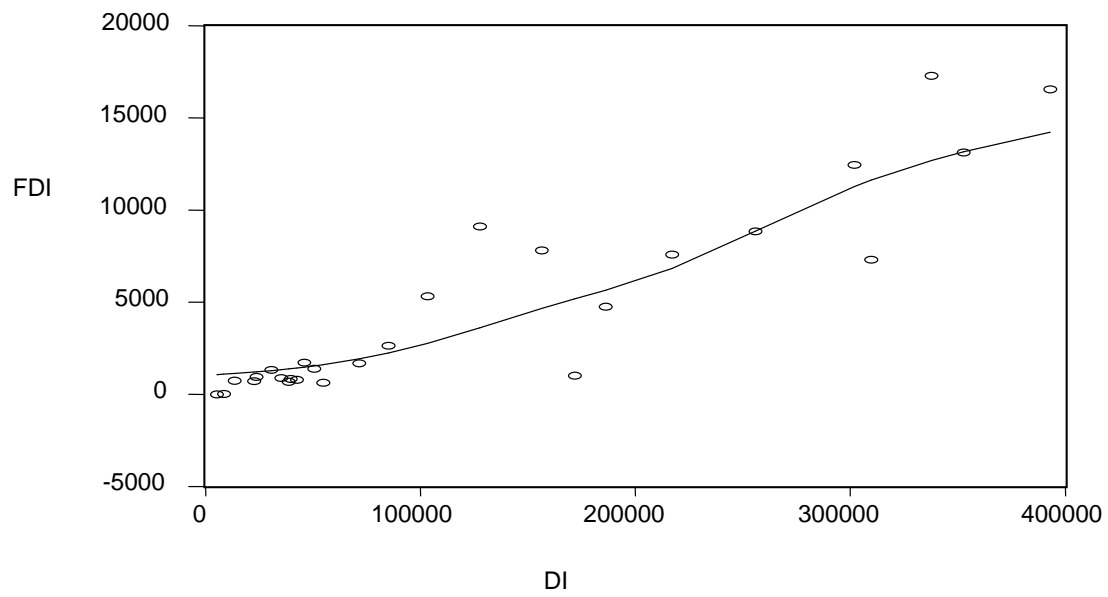

Figure 4: Foeign Direct Investment and domestic investment Kernel Fit (Normal, $\mathrm{h}=58152$ )

The magnitude of the error correction coefficient of the model indicates the speed of adjustment of any disequilibrium toward a long-run equilibrium state. The error correction term is statistically significant at $\mathrm{p}=0.05$ in the economic growth, domestic investment and merchandise trade equations. The significance of $\lambda$ in LY equation implies that economic growth in Sri Lanka adjusts to change

Table 3: Coefficient estimates of error correction models

\begin{tabular}{|lccccc|}
\hline $\begin{array}{l}\text { Dependent } \\
\text { Variable }\end{array}$ & $\mathrm{EC}_{\mathrm{t}-1}$ & $\sum \Delta \mathrm{LY}$ & $\sum \Delta$ LFDI & $\sum \Delta$ LDIN & $\sum \Delta$ LOPEN \\
\hline$\Delta$ LY & -0.134 & 0.5670 & 3.0656 & 0.1891 & -33660 \\
& {$[4.4]$} & $(0.525)$ & $(1.477)$ & $(0.392)$ & $(108804)$ \\
& & $\{2\}$ & $\{2\}$ & $\{2\}$ & $\{2\}$ \\
$\Delta$ LFDI & -0.010 & 0.2226 & 0.7606 & -0.1760 & -74686 \\
& {$[0.106]$} & $(0.125)$ & $(0.352)$ & $(0.093)$ & $(25942)$ \\
& & $\{2)$ & $\{2\}$ & $\{2\}$ & $\{2\}$ \\
$\Delta$ LDIN & -0.300 & 0.4913 & 3.4346 & 0.6322 & -498543 \\
& {$[2.9]$} & $(0.665)$ & $(1.870)$ & $(0.496)$ & $(137796)$ \\
& & $\{2\}$ & $\{2\}$ & $\{2\}$ & $\{2\}$ \\
$\Delta$ LOPEN & 0.201 & $-2.33 \mathrm{E}-07$ & $5.95 \mathrm{E}-06$ & $2.55 \mathrm{E}-06$ & -1.1125 \\
& {$[3.5]$} & $(1.9 \mathrm{E}-06)$ & $(5.3 \mathrm{E}-06)$ & $(1.4 \mathrm{E}-06)$ & $(-2.855)$ \\
& & $\{2\}$ & $\{2\}$ & $\{2\}$ & $\{2\}$ \\
\hline
\end{tabular}


in growth of foreign direct investment, growth in domestic investment and growth in merchandise trade. The result shows that error correction in this equation is -0.134 indicating that when GDP growth is above or below its equilibrium level occurs within the immediate period after a shock and around 1.8 percent of the domestic investment occurs within this period. Similarly the significance of $\lambda$ in LLDIN implies that growth in domestic investment adjusts to changes in GDP, foreign direct investment and merchandise trade. The total elasticity of FDI in relation to GDP is 0.2226 and elasticity of DIN in relation to FDI is 3.43 .

Table 4 shows that the direction of Granger causality is from GDP to FDI since the estimated $F$ value is significant at $5 \%$ level of significance. On the other hand there is a reverse causation from FDI to GDP since the computed $F$ value is statistically significant. Similar Granger causality could be observed in the results from DIN and OPEN to GDP as well as from GDP to DIN and OPEN. The implication of the results is that of the effect of direct growth of FDI on the Sri Lankan economy. These results were affected mainly by the liberalization of economic policy implemented in the country after 1977. As all the years from 19772003 were positive towards FDI, the overall contribution of FDI to economic growth of the country is noticeable. The FDI firms since 1990's were relatively more export oriented as compared to those in the early 1990's. However the results of the study do not fully support this issue.

Table 4: Granger causality test between variables

\begin{tabular}{lccc}
\hline Direction & Number of lags & F statistics & $\begin{array}{c}\text { Granger } \\
\text { Causality }\end{array}$ \\
\hline FDI $\rightarrow$ Y & 4 & 2.567 & Yes \\
Y $\rightarrow$ FDI & 4 & 8.20 & Yes \\
DIN $\rightarrow$ Y & 4 & 3.53 & Yes \\
Y $\rightarrow$ DIN & 4 & 16.84 & Yes \\
OPEN $\rightarrow$ Y & 4 & 8.97 & Yes \\
Y $\rightarrow$ OPEN & 4 & 16.24 & Yes \\
\hline
\end{tabular}




\section{Conclusion}

This study examines the relationship between FDI and GDP in Sri Lanka using data from 1977-2003. The results indicated that FDI is a key determinant of Sri Lankan economic growth after the 1977 period. The empirical results suggest that one long-run equilibrium relationship exists between GDP, FDI, DIN and OPEN. The Engle and Granger error correction approach is then used to investigate the direction of causality flow in the short-run and long-run. The FDI inflows exert an independent influence on economic growth and direction of Granger causation is towards FDI to GDP growth and GDP growth to FDI and hence there is a bidirectional Granger causality between FDI and economic growth. The impact of DIN and OPEN on GDP growth is positive and feedback causality could be observed from DIN and OPEN to GDP as well as from GDP to DIN and OPEN.

In general, the study appears to support the impact of foreign direct investment on GDP growth of Sri Lanka. This finding confirms the relevance of the economic reform programmes in Sri Lanka to reduce macroeconomic instability, remove economic distortions, promote exports and restore sustainable domestic investment for economic growth. However, the country's protectionist trade policies, direct and indirect regulatory barriers that raised the capital cost of foreign firms by $13 \%$ and loss of profits by $30 \%$ may have impeded foreign investment. The low level of development of infrastructure facilities, low investment in human capital, transport, telecommunication facilities, high lending rate, and political instability of the country may have resulted in low investment. In the long term, Sri Lanka needs to boost its human capital and improve its labour market, physical and technological infrastructure and administrative capabilities to induce higher investment.

\section{References}

Athukorala, P. (2003). The Impacts of Foreign Direct Investment and Economic Growth: A Case Study in Sri Lanka. Achievements and Policy Option in W.D Lakshman (eds) Dilemmas of Development. 386-421

Barro, R. (1990). Government Spending in a Small Model of Endogenous Growth. Journal of Political Economy. 98:103-25. 
Boswijk, H.P. and H. Frances. (1992). Dynamic

Specification and Cointegration. Oxford Buletin of Economics and Statistics. 54:369-81.

Choudry, T. (1995). Long-run Money Demand Function in Argentina During 19351962: Evidence from Cointegration and Error Correction Models. Applied Economics. 27:661-67.

Chow, P.C.Y. (1987). Causality Between Export and Industrial Development. Journal of Developmental Economics. 26:55-63.

De Gregrio and P. Guidotti. (1995). Financial

Development and Economic Growth. World Development. 3: 443-48.

Dickey, D.A. and W.A. Fuller. (1979). Distribution of the Estimators for Autoregressive Time Series with Unit Root. Journal of American Statistical Association. 74:427-31.

Engle, R.F. and C.W.J. Granger. (1987). Cointegration and Error Correction: Representation,
Estimation and Testing. Econometrica. 55:251-76.

Fosu, A.K. (1990). Export Composition and the Impact of Exports on Economic Growth of Developing Economies. Economic Letters. 34:6771.

Henriques, I. and P. Sardosky. (1996). Export-led Growth or Growth in the Global Economy. Ambridge, MA:MIT Press.

Johansen, S. and K. Juselius. (1990). Maximum Likelihood Estimation and Inference on Cointegration with Application to the Demand of Money. Oxford Bulletin of Economics and Statistics. 52:169-210.

Jung, W.S. and P.J.Marshall. (1985). Exports Growth and Causality in Developing Countries. Journal of Developmental Economics. 18:1-12.

Lewis, W.A. (1988). On the Mechanics of Economic Development. Journal of Monetary Economics. 22:3-42.

Osterwald-Lenum, M. (1992). A Note With Quantities of 
the Asymptotic

Distribution of the

Maximum Likelihood

Cointegration Rank Test

Statistics: Four Cases.

Oxford Bulletin of

Economics and Statistics.

54:461-72.

Phillips, P.C.B. and P. Perron (1988). Testing for Unit Root in Time Series Regression. Biometrica. 75:335-346.

Solow, R.M. (1956). A Contribution to the Theory of Economic Growth. Quarterly Journal of Economics. 70:65-94.

Watawela, L.R. (1992). Foreign Investment Policies and Foreign Investment in Sri Lanka. Sri Lanka Offprints. 30:5-12.

World Bank. (2002). World Tables. Oxford University Press. 